\title{
VÝZKUM NOVOVĚKÉ HROBKY V KOSTELE SV. JAKUBA VĚTŠÍHO V NEČTINECH
}

\author{
JIŘÍ ORNA - JIŘÍ ŠNEBERGER - MARTIN OMELKA - OTAKARA ŘEBOUNOVÁ - \\ VERONIKA PILNÁ
}

\begin{abstract}
Abstrakt: V rámci prípravných prací na odvlhčení a statickém zajištění základů kostela sv. Jakuba v Nečtinech byla u západního vstupu do kostelní lodi odkryta zděná hrobka, ve které následně proběhl archeologický výzkum. Studie představuje interdisciplinární zhodnocení ziskaného nálezového souboru, který vedle kosterniho materiálu tvořily zejména pozůstatky oděvu a dalši předměty pohřební výbavy. Na vyhodnocení nálezového souboru se kromé archeologů podileli rovněž antropologové, historici a archivárí. Výsledky výzkumu představuji zajímavý př́spěvek $k$ dějinám odiváni a pohřebniho ritu na územi Čech vobdobi raného novověku. Řěsena je také možnost identifikace jedince uloženého do hrobky v interiéru kostela.
\end{abstract}

Klíčová slova: hrobka-antropologie-devocionálie - matriky-oděvy.

\section{Research into a modern-age tomb in the Church of St. James the Greater, Nečtiny}

Abstract: During preparatory work preceding the drainage and structural stabilisation of the foundations of the Church of St. James the Greater in Nečtiny, a masonry tomb was disclosed by the west entrance to the church nave, and it was subsequently archeologically investigated. This study presents an interdisciplinary assessment of the series of finds which included, apart from skeletal remains, particularly the remains of clothing and further grave goods. The finds were assessed by archaeologists, anthropologists, historians and archivists. The results make an interesting contribution to the history of fashion and burial rites in the Czech lands in the early modern age. The issue of the identification of the person interred in the tomb in the church interior was addressed as well.

Key words: tomb - anthropology - devotionalia - registers - clothing.

\section{Úvod}

Mnohdy havarijní stav sakrálních staveb na území České republiky vyvolává nutnost jejich rekonstrukce, která s sebou zpravidla přináší možnost archeologického poznání. Přestože je potenciál tohoto poznání často výrazně prostorově omezen, při výzkumech realizovaných při vnějším obvodu kostelů se daří získávat cenné poznatky k stavebnímu vývoji svatyně i k pohřebnímu ritu (např. Frolík 2017; Dudková a kol. 2018).

Obdobný, nebo spíše ještě vyšší archeologický potenciál však mají výzkumy realizované v interiérech sakrálních staveb. To se týká zejména stavebně historického poznání kostela, ale také dokladů pohřebního ritu (např. Kováčik-Dudková-Lafková 2016; Zezula 2011). Pohřby uskutečněné $\mathrm{v}$ kostelech byly zpočátku umožněny pouze duchovním a společensky výše postaveným osobám, od 17. století si je vymáhali a předpláceli také zámožní měštané (Králíková 2017, 139). Při archeologickém výzkumu těchto hrobů se proto zvyšuje možnost identifikovat pohřbenou osobu, předpokládá to však zpravidla interdisciplinární př́ístup při vyhodnocování výsledků výzkumu.

\section{Okolnosti výzkumu v kostele sv. Jakuba Většího v Nečtinech}

Při přípravě projektu odvlhčení a statického zajištění kostela sv. Jakuba Většího v Nečtinech byla v ř́ijnu 2017 odkryta u západního vstupu do lodě kostela z cihel vyzděná komora (obr. 1). Po otevření prostory se zdálo, že její výplň tvoří stavební sut' a výdřeva valené klenby v různém stadiu rozkladu. Následně proto proběhl zjištovací archeologický výzkum, který měl zjistit, co se nachází pod výše uvedenou výplní. Terénní část výzkumu realizovali pracovníci oddělení starších dějin Západočeského muzea v Plzni. Šlo pravděpodobně o první archeologický zásah v areálu této sakrální stavby. 


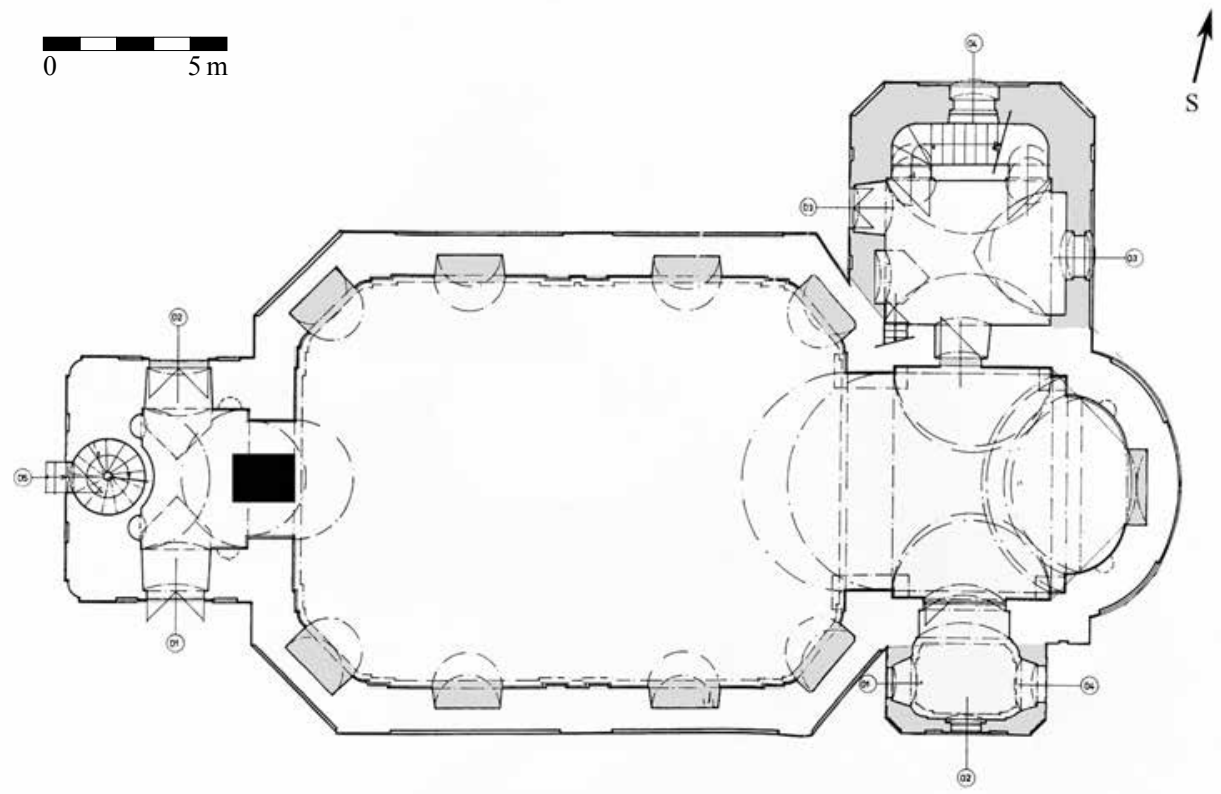

Obr. 1. Poloha hrobky v kostele sv. Jakuba Většího, vyznačena černě. Autoři I. Šlechtová a J. Šneberger.

Abb. 1. Schwarz gekennzeichnete Lage der Gruft in der Kirche St. Jakobus der Ältere. Zeichnung I. Šlechtová und J. Šneberger.

\section{Stručný nástin dějin kostela sv. Jakuba Většího v Nečtinech}

Obec Nečtiny se nachází $30 \mathrm{~km}$ severozápadně od Plzně a $5 \mathrm{~km}$ jihozápadně od Manětína. Nejstarší zpráva o Nečtinech se váže k roku 1169, kdy jsou uvedeny v zakládací listině komendy řádu rytírů svatého Jana v Manětíně (CDB I, č. 246). Jako svědek je na několika listinách v druhé polovině 12. století uveden Předota či Předa z Nečtin (de Neibstin, de Nechetin) (CDB I, 402, 404 č. 363). Oldřich a Předota z Nečtin byli svědky na listinách chotěšovského kláštera z let 1290 a 1291 (RBM, 2739 č. 1499). Za sídlo těchto pánů bývá označována tvrz, která měla stát v místech kostela sv. Jakuba Většího (Kočka 1932, 150). Tato teorie byla odmítnuta s tím, že povrchový průzkum lokality vyloučil možnost existence panského sídla (Knoll 2003, 11). Zde je však třeba vyjádřit pochybnost, že ve druhé polovině 12. století pán z Nečtin sídlil na tvrzi. Tato panská sídla se objevují až od poloviny 13. století. Mohla jim předcházet sídla označovaná jako castellum (kostel; Laval 2016, 69). V tom případě by kostel sv. Jakuba Většího byl původně kamennou románskou stavbou s věží situovanou u západní stěny svatyně. Dodnes se tato stavba v Nečtinech vyznačuje poměrně dominantní polohou, která je pro tato sídla také typická (Laval 2016, 50, 78). Kostely zasvěcené sv. Jakubu se v českých zemích objevují právě ve druhé polovině 12. století (Boháč 1973, 376). Tento sídelní komplex zanikl zřejmě na sklonku 13. století, kdy zde Bavor z Nečtin nechal vystavět raně gotickou svatyni (Kočka 1932, 165), a došlo ke vzniku nového panského sídla - hradu na vrchu Špičák (Knoll 2003, 4). Podobný proces bylo možné sledovat u kostela sv. Petra a Pavla v Liticích (Dudková a kol. 2018, 38, 45). Zatím však pro tuto hypotézu neexistují žádné publikované doklady získané archeologickým nebo stavebně historickým průzkumem. Dodnes se ve zdivu kostela dochovaly doklady gotické fáze stavby - ve zdivu severní strany lodi jsou zřetelné pravidelně otesané kamenné kvádry a zbytky architektonických článků, na nárožích závěru presbytáře jsou zachované části opěrných pilířu (Knoflíček 1995, 3). Od konce 13. století byl kostel sv. Jakuba Většího farní, zdejší farář byl povinen platit pitance 
břevnovskému klášteru (DRC, 153, 188, 216). Za husitských válek byla svatyně pobořena, oprava byla dokončena v roce 1534 (Kočka 1932, 165). Raně barokní sanace, případně přestavba, měla proběhnout po třicetileté válce v polovině 17. století (Knoflíček 1995, 3). Mnohem výraznější zásah proběhl v letech 1750-1752, kdy byla sakrální stavba přestavěna do barokní podoby. Iniciátory této přestavby byli Marie Karolína, vdova po Ferdinandu Felixovi z Kokořova, a její švagr Ignác František z Kokořova (Kočka 1932, 166). Po dokončení základní dispozice byl kostel doplněn o patrovou př́istavbu panské oratoře. Při další přestavbě bylo přízemí oratoře přeměněno na sakristii a z původně uvažované sakristie na jižní straně vznikla malá kaple. V dalších letech proběhly pouze úpravy běžné při udržování kostela, došlo k úpravě části oken a v 90 . letech 20. století proběhla výměna stř̌ešní krytiny (Knoflíček 1995, 4).

V současné době je kostel sv. Jakuba Většího monumentální stavbou situovanou východně od obce v dominantní poloze. Je to jednolodní stavba s presbytářem na východní straně a dvoupatrovou hranolovou věží na západě. K presbytáři s půlkruhovým závěrem přiléhá na severní straně patrová oratoř se sakristií v přízemí a malou přízemní kaplí na jižní straně (Knoflíček $1995,5)$.

\section{Zjišt'ovací archeologický výzkum}

Zjišt’ovací archeologický výzkum proběhl v zahloubené, z cihel vyzděné komoře, jejíž vnější rozměry jsou $222 \times 76 \mathrm{~cm}$. Tento prostor původně překrývala kamenná deska o délce $150 \mathrm{~cm}$ a cihlová valená klenba o délce $72 \mathrm{~cm}$. Právě výdřeva této klenby a stavební sut' tvořily svrchní vrstvy zásypu komory. Pod touto vrstvou se podařilo odkrýt skelet pohřbeného jedince (obr. 2). Ten byl do hrobky uložen v dřevěné rakvi, z které se dochovala kompletní nožní deska (obr. 3). Značně vlhké prostředí interiéru kostela umožnilo zachovat devocionálie a oděv a obuv, ve kterých byl nalezený jedinec pohřben. Rakev byla původně umístěna na cihlových podstavcích. Dno hrobky, které bylo vyzděno z cihel, se nacházelo v úrovni $153 \mathrm{~cm}$ pod současnou úrovní podlahy kostela. Př́i výzkumu byly v hrobové komoře odkryty ostatky pouze jednoho jedince. Superpozice západní stěny hrobky, zachovalé nožní desky rakve a obuvi naznačuje, že komora byla primárně určena pro uložení tohoto jedince.

Stavební sut' tvořící zásyp hrobky je pravděpodobně původní klenba komory. Její zřícení mohlo být způsobeno nadměrnou vlhkostí kostela, která negativně ovlivňuje jeho statiku

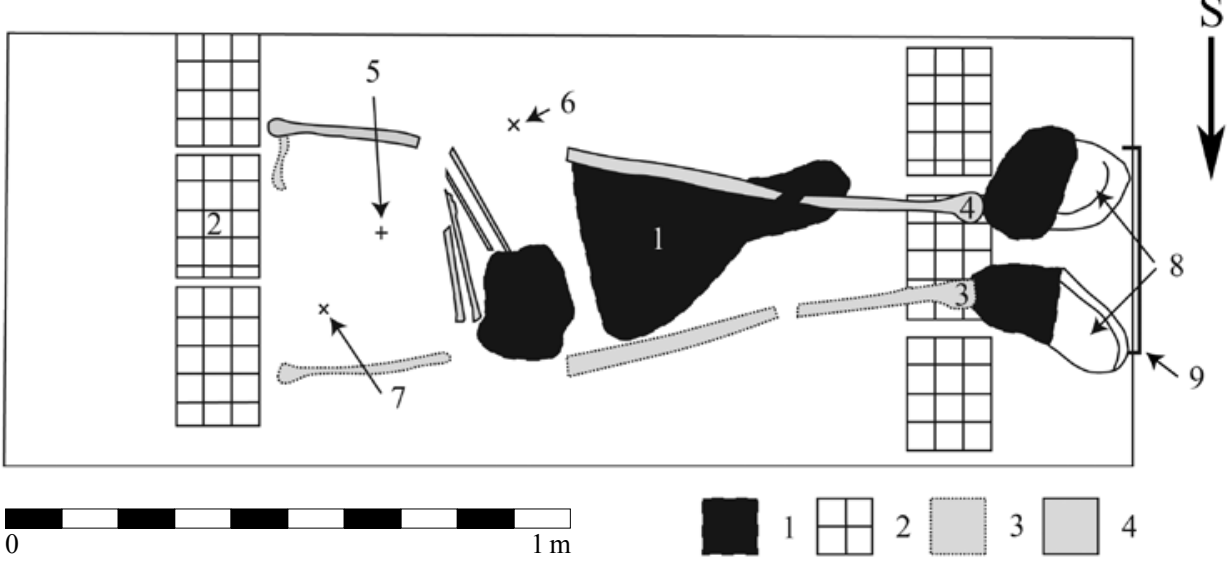

Obr. 2. Kresebná dokumentace nálezového souboru v hrobce: 1 - zbytky pohřebního oděvu, 2 - cihlový podstavec pro rakev, 3 - diageneticky alterované kosti, 4 - zachovalé kosti, 5 - odpustkový kříž, 6 - medailky, 7 - speciální kříž s Janem Nepomuckým, 8 - kožené pantofle, 9 - nožní deska rakve. Autoři I. Šlechtová a J. Šneberger.

Abb. 2. Zeichendokumentation des Fundensembles in der Gruft: 1 - Reste der Bestattungsbekleidung, 2 - Ziegelsteinsockel für den Sarg, 3 - diagenetisch alterierte Knochen, 4 - erhaltene Knochen, 5 - Ablasskreuz, 6 - Medaillons, 7 - gesondertes Kreuz mit Johann von Nepomuk, 8 - Lederpantoffeln, 9 - Fußbrett des Sarges. Zeichnung I. Šlechtová und J. Šneberger. 


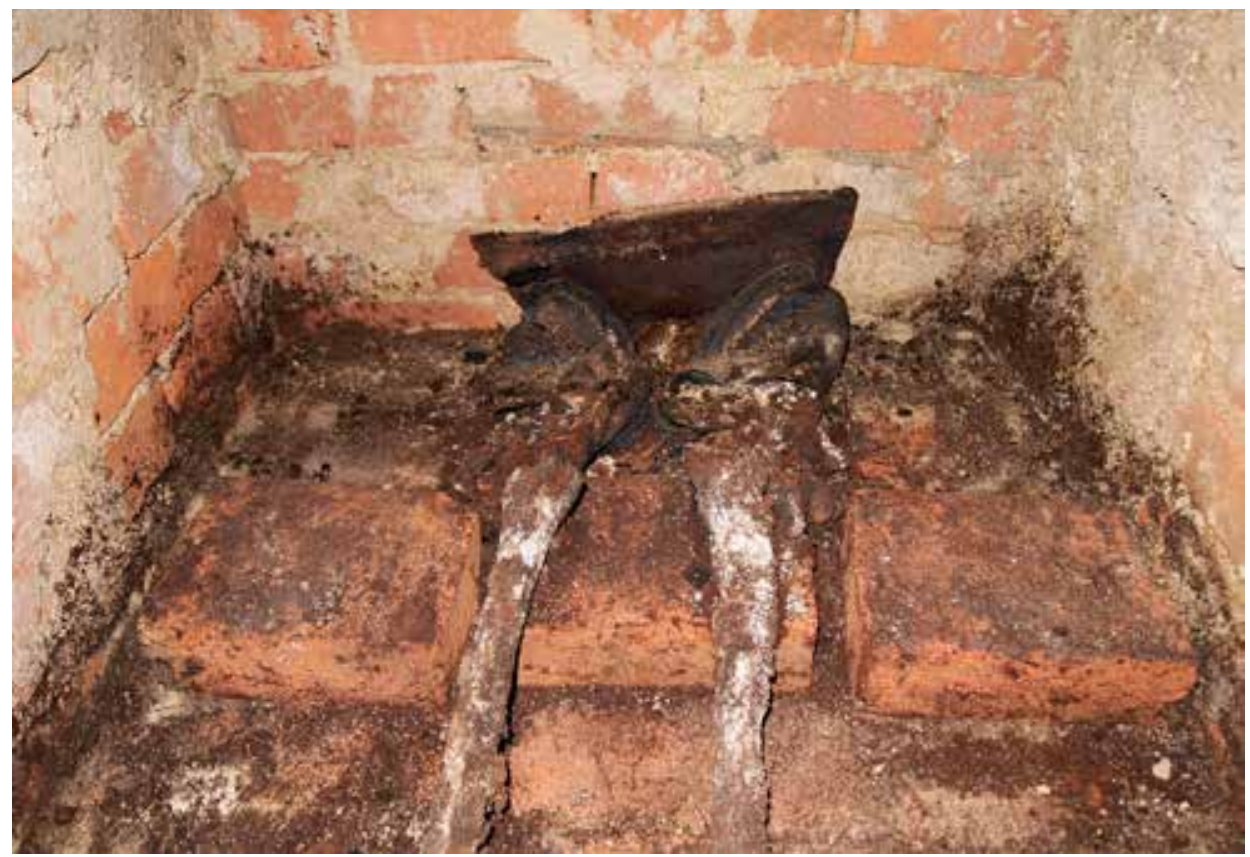

Obr. 3. Detail zachované nožní desky rakve a pantoflů. Foto J. Šneberger.

Abb. 3. Detail des erhaltenen Fußbrettes des Sarges und der Pantoffeln. Foto J. Šneberger.

i v současnosti. Realizaci nové klenby dokládá výdřeva, která tvořila svrchní část zásypu. Nepodařilo se však získat žádné písemné prameny, které by upřesnily, kdy k tomuto stavebnímu zásahu došlo. Každopádně při něm nebylo s jedincem výrazně manipulováno, vyloučit však nelze poškození skeletu. To se zcela prokazatelně týká lebky, nebot' ta byla neanatomicky uložena ve stavební suti.

Nálezový soubor byl po vyzvednutí z hrobky a primárním laboratorním zpracování předán jednotlivým odborníkům $\mathrm{k}$ provedení rozborů s cílem pokusit se identifikovat nalezeného jedince a určit, kdy byl uložen do hrobky (Orna a kol. 2018).

\section{Vyhodnocení nálezu jedince z hlediska biologické antropologie}

U kosterních pozůstatků jedince odkrytého v hrobce v interiéru kostela sv. Jakuba Většího v Nečtinech byl hodnocen stav zachovalosti, byly provedeny základní demografické odhady a na kostech sledovány patrné patologické projevy, či variety.

Zachovalost skeletu byla hodnocena ve dvou úrovních, a to kvantitativně na základě BRI (Bone Representaiton Index) dle Bello et al. $(2006,26)$ a kvalitativně metodou Gordon-Buikstra (1981). Z hlediska obecné zachovalosti jsou ostatky ve špatném stavu, což dokládají i výsledné hodnoty kvantitativní zachovalosti: $48 \%$, a kvalitativní: mezi hodnotami 4 a 5 . Jinými slovy se kosterní ostatky zachovaly v podobě erodovaných dlouhých kostí porostlých plísní, rozpadajících se při dotyku, a několika relativně dobře zachovalých kostí rukou a nohou. Ostatní části skeletu se dochovaly pouze jako otisk v materiálu vzniklý rozkladem měkkých tkání, oblečení a rakve s př́měsí stavební suti, která byla na rakev navršena. Vzhledem ke stavu, ve kterém se nacházely, nebylo možné s ostatky příliš manipulovat, a to počínaje jejich očištěním, až po různé analýzy a hodnocení. Odhad pohlaví byl primárně omezen na metody Walrath-Turner-Bruzek (2004) a Buikstra-Ubelaker (1994) pracující s dimorfními znaky na lebce. Jako další metoda pro 
odhad pohlaví byla využita diskriminační rovnice původně vytvořená pro hodnocení kosterního souboru ze hřbitova u kostela sv. Máří Magdaleny v Plzni (viz Galeta a kol. 2015, 12-16). Pro odhad věku dožití to byly metody hodnocení podle abraze dentice (Lovejoy 1985, 47-56) a obliterace lebečních švů (Masset 1989). Výška postavy jedince byla odhadnuta pomocí matematické metody založené na měření délky dlouhých kostí dle Sjøvold $(1990,45)$.

Na základě výsledků hodnocení se jednalo o dospělého jedince, přičemž obrus zubů naznačuje jeho věk okolo 30 let a obliterace švů 20-39 let. Obrus zubů byl však poměrně atypický a jednostranný. To naznačuje, že chrup nebyl z ortodontického hlediska eugnátní, a tedy i artikulace probíhala nestandardně. Metoda založená na sledování obliterace švů je nepřesná a nespolehlivá, nebot' míra obliterace může být ovlivněna kromě věku i celou řadou dalších faktorů. S relativně vysokou jistotou můžeme alespoň konstatovat, že se jedná o dospělého jedince. $\mathrm{Z}$ hlediska hodnocení pohlaví jsou výsledky obou primárních metod indiferentní. Pro výpočet diskriminační rovnice byl využit rozměr největší délky loketní kosti, tedy vzdálenost nejvyššího bodu olecranonu ulnae od nejdistálnějšího bodu processus styloideus. Výsledek naznačuje, že jedinec by mohl být z $98 \%$ posteriorní pravděpodobnosti mužem. Odhad pohlaví na základě diskriminační rovnice je však v tomto př́ípadě komplikovaný a nelze ho považovat za zcela spolehlivý. Použitá rovnice byla vytvořena na jiném kosterním souboru. Ten je sice místu uložení hodnoceného jedince geograficky poměrně blízký a chronologicky odpovídá, ale přesto zde vyvstává množství problémů, které odhad komplikují. Výsledný odhad je tedy potřeba brát s rezervou. Výška postavy byla, stejně jako diskriminační rovnice, stanovena na základě délky pravé loketní kosti, která se jako jediná zachovala v celé své délce. Jedinec dosahoval výšky v rozmezí $168,5-178,5 \mathrm{~cm}$. Pro přehled jsou výsledky jednotlivých odhadů a hodnocení uvedeny $\mathrm{v}$ tabulce 1 .

Z paleopatologického hlediska je na horní a dolní čelisti jedince v místech okrajů zubních lůžek patrná výrazná kostní resorpce a porosita alveolární kosti. To společně s množstvím přítomného zubního kamene, vymezujícího původní místo gingivodentálního uzávěru, a většími mezerami právě mezi alveolární kostí a zubním kamenem, může ukazovat na přítomnost onemocnění závěsného aparátu zubu (obr. 4). Na prvním a druhém pravém horním třenovém zubu jsou zubní kazy v podobě kavit, které ale byly identifikovány jen na základě toho, že došlo k odlomení zubní skloviny z korunky zubů z důvodu vysychání dentálních tkání. Kromě toho došlo u jedince také k jedné intravitální ztrátě zubu, a to první levé horní stoličky (obr. 5). Vzhledem $\mathrm{k}$ zachovalosti kosterního materiálu není možné s jistotou říci, zda se jedná o ztrátu v důsledku stáří, traumatu, již zmíněného onemocnění závěsného aparátu zubu, nebo z jiných př́íčin. Patrná je také destrukce pravého bradavkového výběžku, neboli processus mastoideus na spánkové kosti (obr. 6). Může se jednat o následek zánětu sluchového kanálku, tzv. chronickou otitis, přecházející v zánět sklípků v bradavkovém výběžku neboli mastoiditis. Případně se také může jednat o cholesteatom (cholesteatoma), tedy nádor vyskytující se nejčastěji ve středním uchu a právě v oblasti bradavkového výběžku (Flohr-Schultz 2009, 100-104). Vzhledem k zachovalosti ostatků ale opět není možné s jistotou říci, o jaký patologický projev se skutečně jedná. Není možné vyloučit, že se nejedná pouze o kostní degradaci způsobenou diagenetickými procesy (Hedges 2002).

Na patře a pravé polovině alveolární kosti horní čelisti a celé alveolární kosti dolní čelisti je zjevná kostěná novotvorba. Jedná se o tzv. palatine torus na horní čelisti (obr. 5) a torus mandibularis na dolní čelisti (obr. 7). Jde o projev mastikačního stresu a genetické predispozice. Spojován je také se změnou složení a př́ípravy stravy, která by měla být zaměřena hlavně na maso zpracovávané vysoušením namísto tepelného zpracování, tedy přechod k tužší stravě. Analogie nejčastěji pochází z populací žijících v oblasti polárního kruhu, jako jsou Eskymáci, Sámové, Island'ané, ale také populace žijící na severu pevninské Evropy (Capasso-Kennedy-Wilczak 1999, 16-18). Etiologie palatine torus a torus mandibularis není zcela jasná a není možné tyto projevy pevně spojovat jen s některými konkrétními populacemi, nebo se dokonce pokoušet na jejich základě interpretovat původ zkoumaného jedince. 


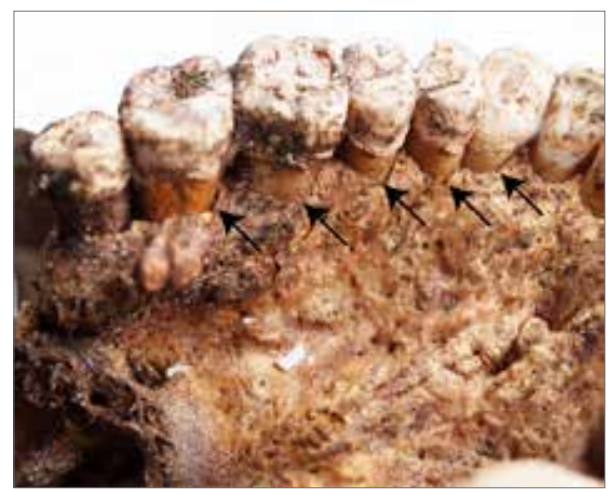

Obr. 4. Patrné mezery mezi alveolární kostí a zubním kamenem značící výraznou resorpci kosti. Foto J. Šneberger. Abb. 4. Die gut erkennbaren Lücken zwischen dem Alveolarknochen und dem Zahnstein weisen auf eine ausgeprägte Knochenresorption hin. Foto J. Šneberger.

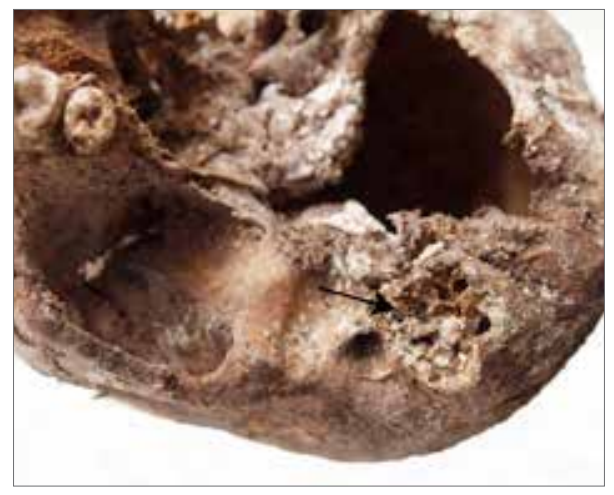

Obr. 6. Destrukce pravého bradavkového výběžku na spánkové kosti. Foto J. Šneberger.

Abb. 6. Zerstörung des rechten Warzenfortsatzes am Schläfenbein. Foto J. Šneberger.

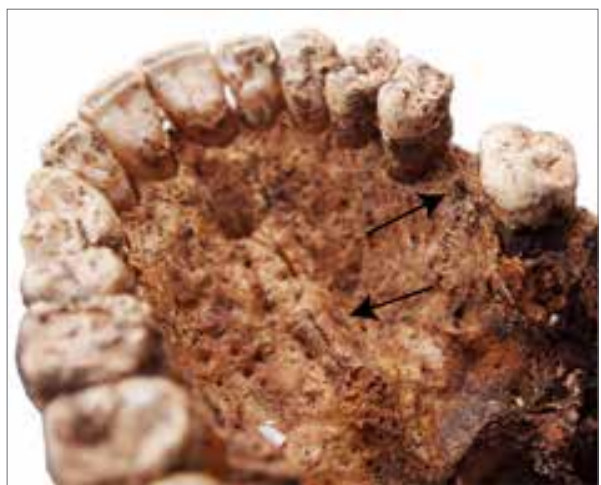

Obr. 5. Intravitální ztráta první levé horní stoličky a palatine torus na patře horní čelisti. Foto J. Šneberger.

Abb. 5. Intravitaler Verlust des ersten linken oberen Backenzahns und Torus palatinus am Gaumen des Oberkiefers. Foto J. Šneberger.

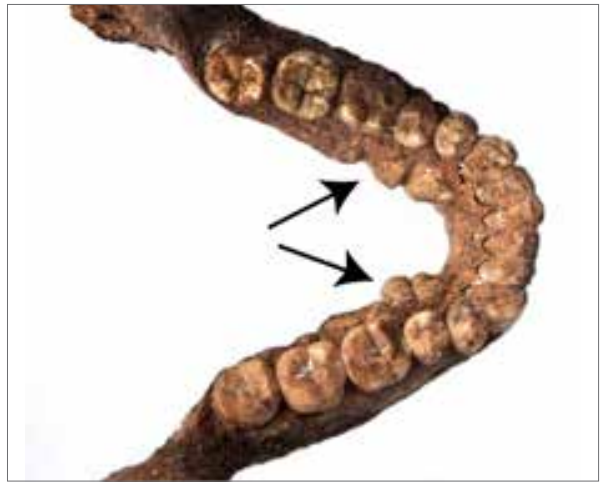

Obr. 7. Torus mandibularis na dolní čelisti. Foto J. Šneberger.

Abb. 7. Torus mandibularis am Unterkiefer. Foto J. Šneberger.

\begin{tabular}{|c|c|c|c|c|c|c|}
\hline \multicolumn{2}{|c|}{ Věk } & \multirow{2}{*}{ Pohlaví } & \multicolumn{2}{c|}{ Výška postavy (cm) } & \multicolumn{2}{c|}{ Zachovalost } \\
\cline { 4 - 7 } Skupina & Roky & & Průměr & Rozsah & Kvantitativní & Kvalitativní \\
\hline adultus & $20-39$ & I & 173,6 & $168,5-178,5$ & $48 \%$ & $4-5$ \\
\hline
\end{tabular}

Tab. 1. Shrnutí výsledků hodnocení jedince z krypty kostela sv. Jakuba Většího v Nečtinách.

Tab. 1. Zusammengefasste Ergebnisse der Auswertung des Individuums aus der Krypta der Kirche St. Jakobus der Ältere in Nečtiny.

\section{Rozbor devocionálií}

V rámci výzkumu byla v kryptě vyzvednuta, mimo jiné, i pětice předmětů z pohřební výbavy dokládající projevy náboženské úcty. $Z$ hlediska dobového pohřebního ritu byl z těchto předmětů nejdůležitější dnes již částečně rozpadlý dřevěný latinský křiž s kovovými aplikacemi. Konce tř́i ramen kř́iže pokrývala nezdobená kování hranatého tvaru. Na spodní části 
svislého břevna je umístěna plastika Adamovy lebky se zkřriženými hnáty reprezentující Golgotu, v centrální části plasticky provedená postava ukřižovaného Krista, nad jehož hlavou se nachází identifikační nápisová tabulka INRI (obr. 8).

Artefakt lze zařadit mezi tzv. kříže do ruky, odpustkové kř́iže, které věřící ve svých posledních chvílích svírali v ruce a se kterými byli následně uloženi do hrobu. Křiže zaopatřoval kněz církevními odpustky, ty platily vždy výhradně pro konkrétního umírajícího. Křŕž měl umírajícímu pomoci ke vstupu na nebesa, a proto bylo nemyslitelné, aby přešel, po smrti jeho držitele, do vlastnictví další osoby (Omelka-̌̌ebounová-Šlancarová 2009, 1019-1020).

Další dřevěný latinský křížek ze souboru (obr. 9), respektive jeho torzo, svou formou odpovídá kř́ižkům řazeným $\mathrm{v}$ odborné literatuře $\mathrm{k}$ bavorské řezbářské produkci $\mathrm{z}$ regionu Oberammergau z konce 18. až konce 19. století. Srovnávací ukázkou předpokládané produkce tohoto výrobního okruhu je kř́ižek pocházející z alpské oblasti datovatelný do konce 18. století (Keller 2010a, 226, Kat. Nr. 6.1031, zde obr. 10). Výzdobu křížů přisuzovaných řezbářům z Oberammergau nezrrídka tvoří zobrazení ukřižovaného Krista, pod kterým se nachází postava Panny Marie Bolestné. Křriže tohoto typu, zpravidla ve větší velikosti, sloužily často jako relikviářové schránky. V našem případě však pravděpodobně byl kříž původně součástí růžence ve funkci apotropaické svátostky. Pro špatný stav a torzovitost popisovaného předmětu je nutné chápat

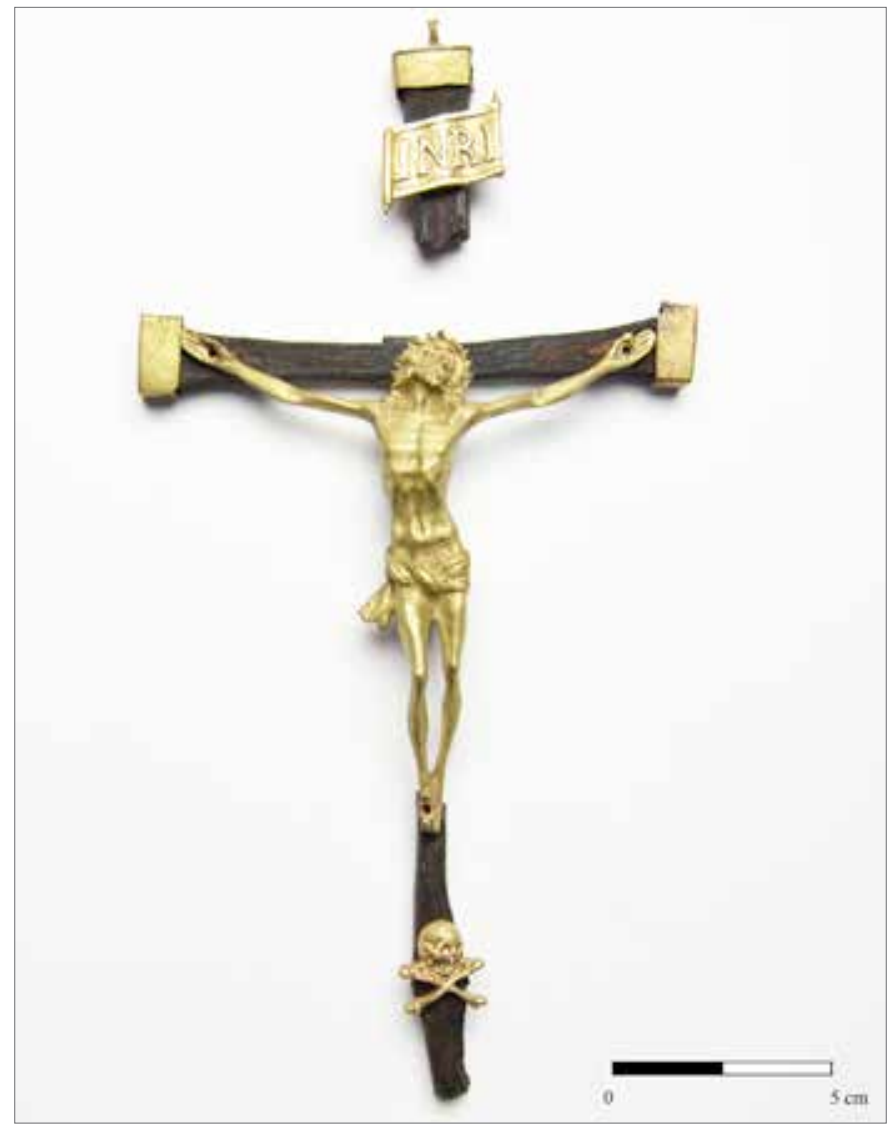

Obr. 8. Kříž zaopatřený církevním odpustkem pro umírajícího byl v období baroka nezbytnou součástí katolické pohřební výbavy. Foto I. Šlechtová.

Abb. 8. Ein mit kirchlichem Ablass versehenes Kreuz für den Sterbenden war während der Barockzeit ein unentbehrlicher Bestandteil der katholischen Grabbeigaben. Foto I. Šlechtová. 


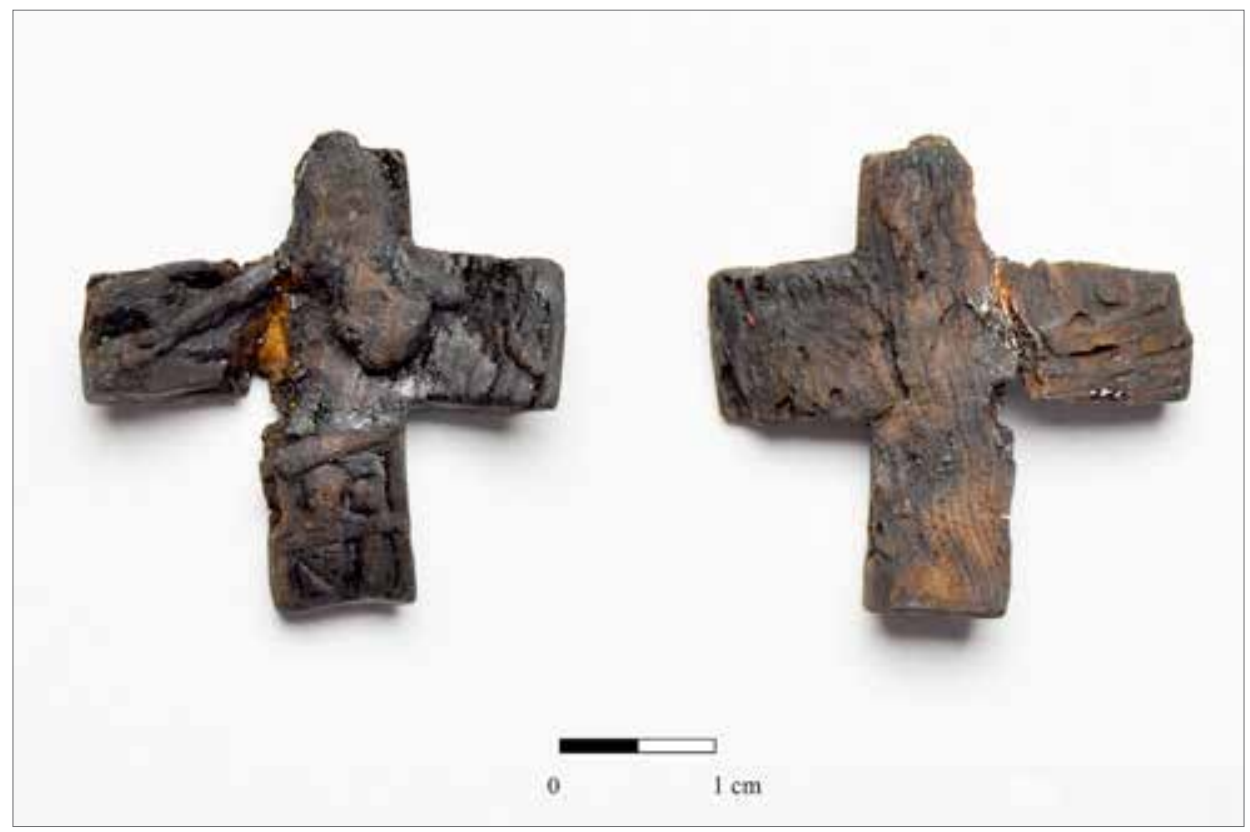

Obr. 9. Zlomek dřevěného kř́ǐ̌ku. Tento typ latinského kř́ǐzu přisuzuje Keller (Keller 2010a) řezbářům z oblasti Oberammergau. Foto I. Šlechtová.

Abb. 9. Fragment des Holzkreuzes. Dieser Typus eines lateinischen Kreuzes schreibt Keller den Schnitzern aus der Region Oberammergau zu (Keller 2010a). Foto I. Šlechtová.

určení původu pouze jako orientační. Nelze vyloučit, že se jedná pouze o napodobení produkce řezbářů z oblasti Oberammergau.

Třetí předmět ve tvaru latinského kříže byl vyroben z mosazi. Na jedné jeho straně se nachází postava ukřižovaného Krista s naznačenou muskulaturou, na druhé potom postava Jana Nepomuckého s křížem v náručí doplněná ve spodní části identifikační zkratkou S. IOHN. Kolem jeho hlavy je v náznaku ztvárněna trojice andělů (obr. 11).

Svou formou členění odpovídá předmět křížkům nesoucím nejčastěji nápis či nápisovou zkratku VITAM PRAESTA PVRAM, př́ípadně MARIA MATER GRATIA (blíže k problematice viz

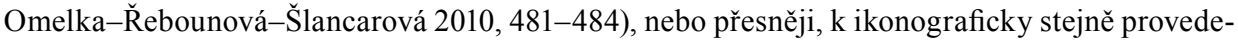
ným křižkům, které nenesou žádný nápis a jsou přibližně o 20 procent menší než výše uvedené závěsky s nápisy.

Zásadní rozdíl mezi výše popsanými křížky typu Immaculata conceptio a posuzovaným křižem je přítomnost postavy Jana Nepomuckého na místě, kde se tradičně umist'uje vyobrazení postavy Panny Marie Immaculaty. Obdobný křížek z odborné literatury zatím neznáme.

I tento křižek lze chápat jako apotropaický předmět, který byl původně součástí růžence.

Vedle kř́iže a křížků se v souboru nacházely i dvě medailky. U první z dvojice lze konstatovat, že se jedná o obecně ochrannou svátostku, která náleží $\mathrm{k}$ vůbec nejrozšířenějším typům barokních svátostek. Její zobrazení propaguje kult Panny Marie a Ježíše Krista obecně, mnohdy jsou jejich busty doplněny opisem MATER SALVATORIS (Matka Spasitele) a SALVATOR $M V N D I$ (Spasitel světa), zdůrazňující mesiášský rozměr osoby Ježíše Krista. V našem případě byla zkratka nápisu MATER SALVATORIS doplněna o zkratku fráze O.P.N. (Ora pro nobis Oroduj za nás!) a zkratka nápisu SALVATOR MUNDI o zkratku prosby SA.N. (Salva nos - Spas nás!; obr. 12). 


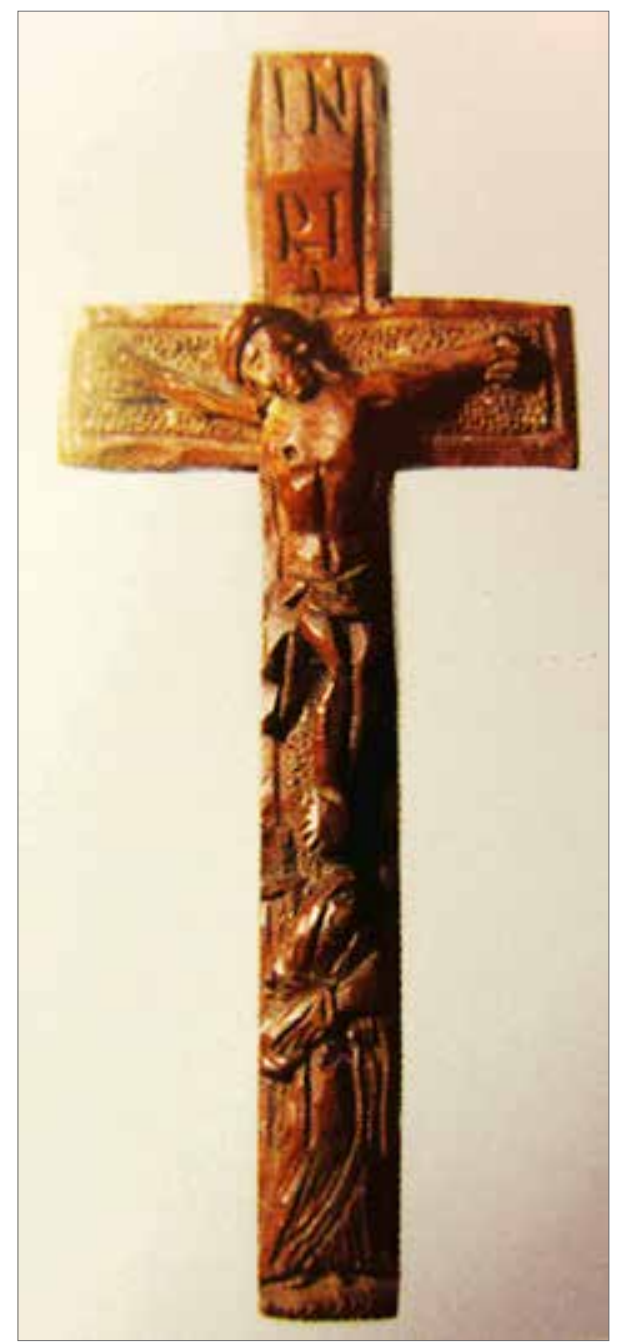

Obr. 10. Předpokládaná původní podoba křížku. Podle Keller 2010a, 226, Kat. Nr. 6.1031.

Abb. 10. Mutmaßliche ursprüngliches Aussehen des Kreuzes. Nach Keller 2010a, 226, Kat. Nr. 6.1031.
Druhá medailka je kruhový medailon s postavou sv. Benedikta na jedné a motivem Benediktova znamení na druhé straně představující jednu ze základních podob Benediktových feniků. Svatý Benedikt je zde zobrazen stojící, v mnišské kutně, s křižkem a artikuly benediktinského řádu (obr. 13). Mitra u jeho nohou symbolizuje postavení Benedikta uvnitř církevní hierarchie, havran u jeho levé nohy odkazuje na legendu o otráveném chlebu spojenou právě s postavou sv. Benedikta. Druhou stranu svátostky zcela vyplňuje kř́ǐz sv. Benedikta (vysvětlení jednotlivých zkratek viz Omelka 2006, 146-148).

Ač to nemůžeme jednoznačně doložit, je pravděpodobné, že poslední čtyřri popsané devocionálie, dvě ve tvaru kříže a dvě medailky původně náležely $\mathrm{k}$ jedinému nezachovanému - růženci.

Na rozdíl od současné podoby růžence, jehož nejdůležitější části tvoří tzv. credo-kříž symbolizující modlitbu Apoštolské vyznání víry, soubor menších korálků symbolizujících modlitbu Zdrávas Maria a větších korálků symbolizujících modlitbu Otče náš, se jeho barokní forma částečně lišila - vedle proměnlivého počtu desátků hlavně častým připojováním dalších ochranných předmětů, které měly účinnost růžence ještě více po-

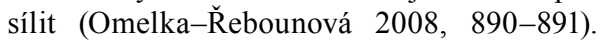
Většinou se jednalo o svátostky ve tvaru oválů či kruhů, ale i atypických tvarů. Zmiňme např́iklad tvar „housliček“, který je doložen u medailek z chrámu Panny Marie Vítězné na Malé Straně v Praze propagujících Pannu Marii Karmelskou společně s Pražským Jezulátkem. Ojedinělé nebyly ani závěsky ve tvaru různých podob křrižů. Tedy kř́ižů, či lépe řečeno křižkůn, které vedle základní symboliky latinského kř́že, potažmo Krista, propagovaly i další symboly katolického kultu, nejčastěji

Pannu Marii, některého z katolických světců, církevní událost či konkrétní poutní místo (Omel-

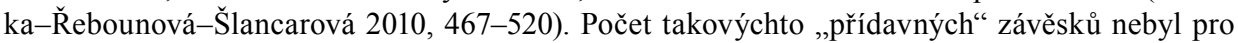
růženec v období druhé poloviny 18. století nijak limitován. Růžence se čtyřmi či více závěsky byly běžné, byt' ne nejčetnější.

Ačkoliv z torza růžence máme zachovány dokonce dva závěsky ve tvaru kříže (křrižku), ani jeden $z$ těchto prredmětů nereprezentoval tzv. credo-kř́iž. Výzdoba a způsob provedení vyzvednutých kř́ižků totiž neodpovídá formě credo-křížỏ známých pro pozdní baroko. Ty se nejčastěji skládaly ze tří soustružených segmentových korálků a jako materiál na jejich výrobu se zpravidla používaly kost nebo dřevo. Dá se proto oprávněně předpokládat, že i náš credo-kř́iž byl vyroben ze dřeva, a stejně jako korálky symbolizující modlitby Zdrávas Maria a Otče náš se nedochoval. 


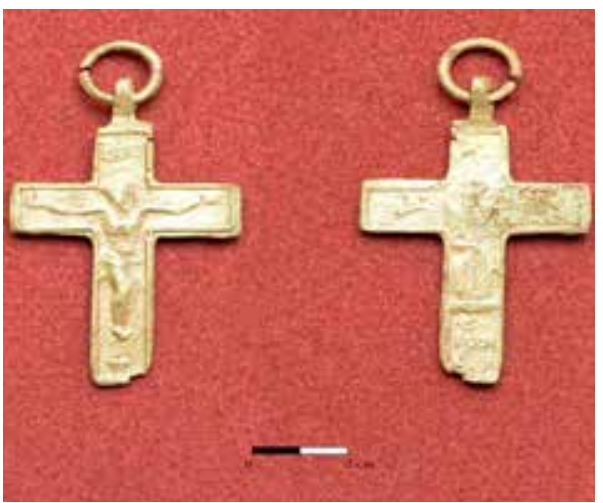

Obr. 11. Křížek zdobený vyobrazením ukřižovaného Krista na jedné straně a postavy Jana Nepomuckého na straně druhé. Foto I. Šlechtová.

Abb. 11. Mit der Darstellung von Jesus am Kreuz auf der einen Seite und der Figur von Johann von Nepomuk auf der anderen Seite verziertes Kreuz. Foto I. Šlechtová.

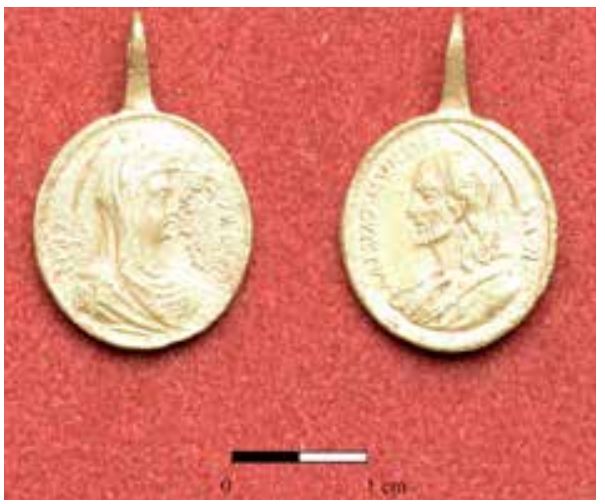

Obr. 12. Obecně ochranný medailon propagující kult Panny Marie a Ježíše Krista. Foto I. Šlechtová.

Abb. 12. Den Marien- und Jesuskult propagierendes Schutzmedaillon. Foto I. Šlechtová.

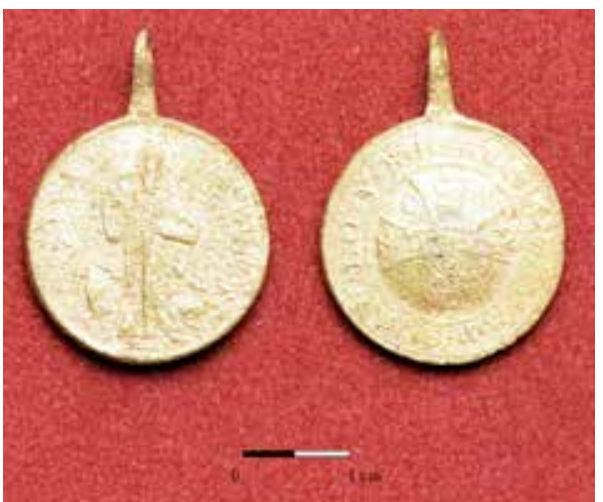

Obr. 13. Kruhový medailon s postavou sv. Benedikta a motivem Benediktova znamení. Foto I. Šlechtová.

Abb. 13. Rundmedaillon mit der Figur des HI. Benedikt und dem Motiv von Benedikts Zeichen. Foto I. Šlechtová.
Oproti dnešní formě růžence je zajímavé i pravděpodobné původní umístění dřevěného latinského kř́žzu na nedochovaném růženci, které lze odvodit z dobové analogie (Keller 2010, 317, Kat. Nr. 2.594), u níž je stejně provedená řezba připojena jako apotropaická svátostka až pod segmentový credo-kř́iž (obr. 14). V druhé polovině 18 . století bylo takovéto, dnes již nepoužívané, umístění ochranných medailek a speciálních křížků na růžencové šňůře běžné.

\section{Rozbor matričních záznamů}

Vzhledem k charakteru a předpokládané dataci předmětů pocházejících $\mathrm{z}$ hrobového inventáře nalezeného jedince (2. polovina 18. století) byly v rámci archivní rešerše zpracovávány záznamy o pohřbech uskutečněných při farním kostele sv. Jakuba Většího v Nečtinech v letech 1735 až 1800. Jde o záznamy vedené v knihách zemřelých pro Nečtiny a zámek Preitenstein uložených ve fondu Státního oblastního archivu v Plzni (Sbírka matrik západních Čech [SMZČ], sign. Nečtiny 20 [1784-1846], Nečtiny 22 [1784-1883] a Nečtiny 29 [1735-1784]).

V souvislosti s místem nálezu se pozornost soustředila především na zápisy dokumentující pohřby do interiéru kostela. V knize s nejstaršími zápisy, z let 1735-1784, která sloužila pro evidenci zemřelých ze vsí Březín (Wirschin), Doubravice (Doubrawitz, Dobrawitz), Lešovice (Leschowitz), Nečtiny (Netschetin), Nové Městečko (Deutsch Neustadtl, Neustadtl), Plachtín (Plachtin), Mezí (Mösing) a nečtinského zámku (Preitenstein), se však takových podařilo doložit pouze šest. Důvodem je především nedostatečná informační hodnota provedených zápisů. Ty se, co se místa pohřbu týče, v naprosté většině omezovaly pouze na uvedení názvů dvou obcí, kam mohli obyvatelé farnosti kostela sv. Jakuba Většího své mrtvé pohřbívat, tedy bud' na jméno obce Nečtiny, nebo Březína, s pohřebním okrskem při kostelu sv. Bartoloměje. Ve 40. a 50. letech 18. století dokonce není, až na výjimky, místo pohřbu v matrice uváděno vůbec.

Uvedenými výjimkami byla trojice pohřbů uložených v kostele, doložených zápisy $z$ druhé poloviny 50 . let 18 . století. Do interiéru novostavby, pod chórem, pak bylo $\mathrm{v}$ roce 


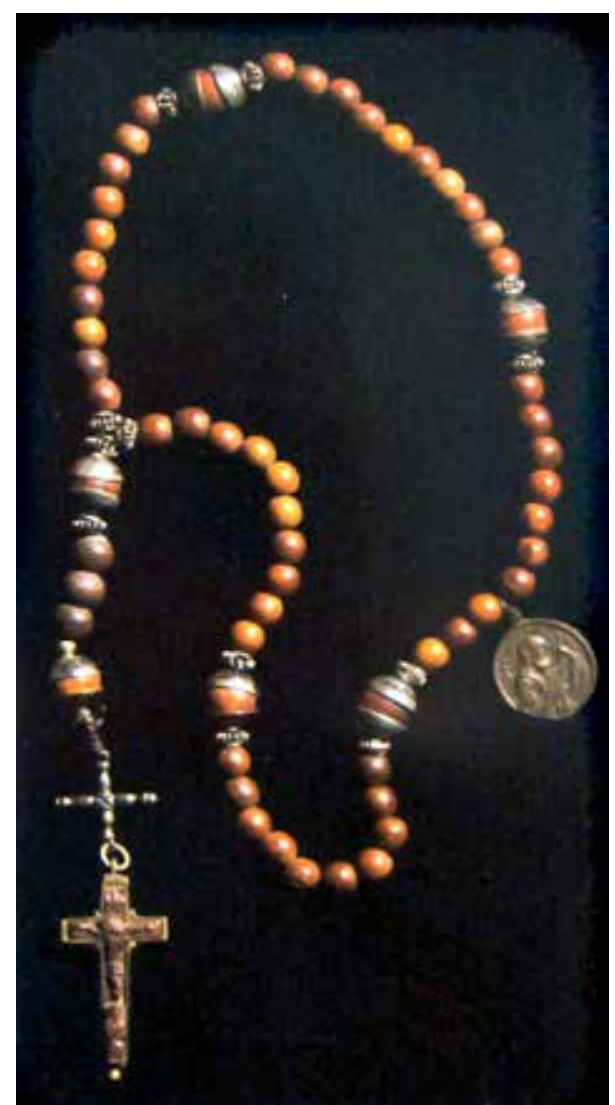

Obr. 14. Růženec z 18. století s ochrannými závěsky. Podle Keller 2010, 317, Kat. Nr. 2.594.

Abb. 14. Rosenkranz aus dem 18. Jahrhundert mit Schutzanhängern. Nach Keller 2010, 317, Kat. Nr. 2.594.
1756 uloženo tělo čtyřicetileté Terezie Razímové, manželky hospodářského úředníka nečtinského zámku Jana Matěje Razíma (pohřbena 2. 8. 1756 ,sub choro“, sign. Nečtiny $29,105)$, v roce 1757 tělo jednatřicetileté Marie Augustiny, provdané de Ramponi (pohřbena 23. 1. 1757 pod chórem z pravé strany, ,Sub choro ex parte dextera") a v roce 1758 další manželky Jana Matěje Razíma, devětatřicetileté Františky Nepomuceny Razímové (pohřbena 7. 1. 1758 vedle předchozí Razímovy manželky, ,penes antecendetem ejusdem Dma Conthoralem in Ecclesia Parochiali“, Nečtiny 29,111$){ }^{1}$

Zlom $\mathrm{v}$ množství zapisovaných údajů nastal až po provedení kanonické vizitace v září 1760. Teprve v důsledku této církevní kontroly byli zjevně místní duchovní správci donuceni k zavedení předpisového matričního zápisu, v němž se, mimo jiné, řádně zaznamenávalo i přesné místo uložení zemřelých.

$\mathrm{V}$ průběhu 60 . a na počátku 70 . let 18. století tak bylo možné mezi pohřby provedenými kolem kostela (,penes ecclesiam“) zachytit také několik pohřbů provedených $\mathrm{s}$ určitostí prímo v kostele. ${ }^{2} \mathrm{~V}$ roce $1766 \mathrm{zde}$ byla uložena sama stavitelka nového kostela, čtyřiapadesátiletá hraběnka Marie Karolina z Kokořova, rozená hraběnka de Hartig. Byla pohřbena 28. 4. uvedeného roku ,in Presbyterio hujus Ecclesiae Parochialis", tedy v presbytáři zdejšího chrámu (Nečtiny 29, 147). ${ }^{3}$ O pět let později, dne 7. 7. 1771, byl do stejné krypty Kokořovců (,,in Crypta familiae

Kokorzowetz"), kam byla předtím v roce 1766 uložena i Marie Karolina, slavnostně pohřben Ferdinand Filip, hrabě z Kokořova, zesnulý dne 3. 7. 1771 ve svém domě v Praze ve věku 43 let (Nečtiny 29, 169). A konečně, v listopadu roku 1771 byl do nečtinského kostela pochován místní dlouholetý farní správce, curatus Martin Kunerl. Kunerl zahájil v Nečtinech kariéru jako kaplan (v matrice je $\mathrm{v}$ této funkci zaznamenán v roce 1736), po smrti místního faráře Martina Eysenkolba v roce 1738 krátce zastával post dočasného duchovního správce (administrátora), od roku 1739 působil ve zdejší farnosti jako řádný duchovní správce, tedy farář. Zemřel ve věku 65 let (Nečtiny 29, 172).

\footnotetext{
1 Pro úplnost, sám Jan Razím zemřel v roce 1766, ve věku 46 let, a byl pohřben nikoliv se svými manželkami uvnitř kostela sv. Jakuba, nýbrž na hřbitově kolem kostela (Nečtiny 29,146$)$.

2 Zde je třeba uvést, že několik prvních zápisů, provedených bezprostředně po vizitaci, v období od záři 1760 do května 1761 , se vyznačuje až přehnanou formální pečlivostí a uvádí u několika po sobě provedených pohřbů (celkem 15 případů) uložení „in Ecclesia S. Jacobi Maj. Aposto$l i “$, čili do kostela sv. Jakuba Většího (Nečtiny 29, 122-125). Podle těchto záznamů by měli být uvniťr kostela pohřbeni např. Josef, dvanáctiletý syn šafáře Josefa Löfera (26.9. 1760), šestašedesátiletý nečtinský tkadlec Jan Michal Bayer (27. 10. 1760), osmasedmdesátiletý nečtinský krejčí Matyáš Pleyer (26. 12. 1760), Karel, tř́letý synek skláře Jana Jiř́iho Kantzla (27. 12. 1760) nebo dvaašedesátiletý Václav Kolmer z Nového Městečka (30. 12. 1760). Tyto záznamy je však třeba ve vztahu k místu uložení pohřbu interpretovat velice opatrně. Už charakter pohřbených osob napovídá tomu, že se jedná o běžné obyvatelstvo nižších a stř̌edních sociálních vrstev, u nichž je pohřeb v kostele spíše nepravděpodobný, a formulace ,in Ecclesia“ je v jejich případech používána nesprávně.

3 Její srdce však bylo na základě jejího přání z těla vyjmuto, aby mohlo být přeneseno do rodinné hrobky Kokořovců ve Žluticích (Nečtiny 29 , 147), kde od roku 1746 spočívalo tělo hraběnčina manžela, hraběte Ferdinanda z Kokořova.
} 
Kam přesně byl v kostele pohřben, matrika bohužel neuvádí. Již v průběhu roku 1770 se pod vlivem josefínských reforem zápisy vrací k bývalé strohosti a nadále se, až na výjimku u pohřbu Martina Kunerla, při uvádění pohřebního místa omezují pouze na jméno obce, kde se prŕíslušný hřbitovní areál nacházel. Zda byl tedy např́íklad další duchovní správce, třiašedesátiletý Jan Kornélius Ludwig, jehož pohřeb byl vykonán 27. 6. 1780, rovněž pochován v interiéru kostela, není z matričního zápisu zř̌jmé.

Ačkoliv byla matriční kniha pro zápisy zemřelých zahrnující obyvatelstvo Nečtin a přilehlého zámku vedena až do roku 1786 , v roce 1784 k ní přibyly dvě další. První, vedená do roku 1846, sloužila od roku 1785 výhradně pro evidenci lidí zemřelých na území nečtinské obce. Druhá matriční kniha evidovala jednak služebnictvo a úředníky, kteří pracovali pro místní zámek označovaný dobovým názvem „Preittenstein“, v případě zaměstnancủ žijících přímo na zámku nebo přilehlých staveních („Dorf Preittenstein“) se mohlo jednat i o členy jejich rodin, jednak obyvatelstvo ze vsí Nové Městečko a Plachtín. Kniha zaznamenává úmrtí těchto lidí v letech 1784-1883.

Ani v jedné z nově založených knih se však u jednotlivých záznamů neuvádí místo pohřbu. Zápisy registrují pouze den úmrtí, den pohřbu, jméno a stav/profesi zemřelého, jeho věk, pohlaví, náboženské vyznání, předpokládanou prríčinu smrti, dům, kde zemřel, a jméno zaopatřujícího a pohřbívajícího kněze. Zda mohl být některý ze zde uvedených zemřelých pohřben uvnitř kostela sv. Jakuba, nelze $\mathrm{z}$ těchto matričních zápisů prokázat. Nicméně v souvislosti s nařízeními Josefa II. o zákazu pohřbívání v interiérech chrámů a dalšího využívání nebo nového zřizování rodinných hrobek v kostelech (rezoluce Josefa II. zakazující pohřbívání v kostelech a hrobkách, vydaná 21. 3. 1782; dvorní rozhodnutí ze dne 1. 12. 1783 rušící zcela rodinné hrobky v kostelech) nelze předpokládat, že by se po roce 1782 až do konce sledovaného období uvnitř kostela pohřbívalo.

\section{Rozbor fragmentů usně}

Z hrobky bylo vyzvednuto celkem 23 fragmentů usně. Na základě rozboru jednotlivých fragmentů a jejich kompletace bylo potvrzeno, že se jedná o pánské pantofle s nízkým plátkovým podpatkem. Ze známek opotřebování patrných na některých dílcích lze usuzovat, že obuv byla nošena a do rakve byla použita druhotně. Obuv byla vyrobena s největší pravděpodobností $\mathrm{v}$ př́ípadě svršku z tř́sločiněné hovězí usně bez výrazných úprav povrchu a podešve ze spodkové usně téhož živočišného původu. V některých místech byly patrné známky nedokonalého kožedělného zpracování, nebot' se na povrchu stále vyskytují rezidua červenohnědých zvířecích chlupů v délce kolem 1-2 mm. Fragmenty jsou v současné době zcela oddělené, jelikož došlo $\mathrm{k}$ rozpadu jak šicího materiálu, tak dřevěných floků.

Podle rozboru jednotlivých fragmentů lze říci, že se jednalo o pantofle na nízkém podpatku se symetrickou podešví (obr. 15). Podpatek tvořily až tři plátky spodkové usně, což je dnes obtížně určitelné, nebot' se nedochovaly všechny plátky zcela neporušené. Pro zpevnění podpatku bylo využito dřevěných floků, které na patních dílcích utvářely dekorativní vzor. Floky lemovaly vnější půlkruhový okraj a ve středu paty čtyři kusy floků tvořily písmeno T. Obuv byla vypracována pomocí rámové techniky (Goubitz 2007, 91-98). Součástí konvolutu jsou i zbytky spojovacího rámku vždy ve dvou částech pro každý kus. Zajímavý je tvar svršku, který je na horním okraji vykrojený do špičky. Špička byla modelována do lehce zaobleného tvaru. Aby obuvník špičky snadněji vytvaroval, vytvořil na špičce několik drobných skladů. Špička tvarově odpovídá druhé polovině 18. století (Štýbrová 2009; Vaňková-Pilná 2013, 83-89). Zajímavým prvkem je dvojitá vrstva usně použitá ke zhotovení nártového dílce. Dílec byl pro každý kus připraven dvakrát a sešit rubovými stranami k sobě, což mělo zvýšit odolnost dílců pro nošení.

Užití pantoflů jako pohřební obuvi je známo již z 16. století. Např́iklad Maxmilián II. a Rudolf II. měli do rakve obuty symetrické pantofle $\mathrm{z}$ hedvábného sametu a s podešvemi zhotovenými z korku (Bravermanová-Čierna 1997, 363-385; Bravermanová-Kobrlová-Samohýlová 1995 , 497-521). V 18. století byly pantofle jako typ obuvi velmi oblíbené. V dámské módě 


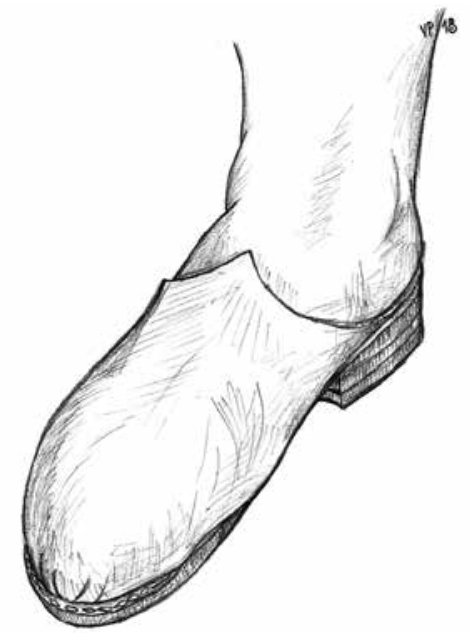

Obr. 15. Kresebná rekonstrukce tvaru obuvi. Autorka V. Pilná.

Abb. 15. Zeichenrekonstruktion des Schuhwerks. Zeichnung V. Pilná. se uplatňovaly i jako obuv do exteriéru, ale u mužů se jednalo o obuv určenou pro neformální okamžiky a odpočinek. Ve stejném období tento typ obuvi v Encyklopedii aneb Racionálni slovnik věd, uměni a řmesel autoři uvádějí pod označením claques (DiderotD’Alembert 1763, díl III, vyobrazení Cordonnier et cordonnier-bottier, obr. 17). Pro dámské pantofle byly typické výšivky a potahování svršku luxusní textilií jako v případě dvou dochovaných půlpárů, barokního a rokokového, z německého muzea kůže v Offenbachu, anebo ještě starších vyšívaných pantofličků datovaných kolem roku 1610 z Buchlova (Gall 1980, inv. č. 6.13.31, 6.14.69; SZ Buchlov, inv. č. BU2243a a BU2243b). Naopak pánský pantofel datovaný kolem roku 1650, který byl součástí pohřební výbavy z německého Kardenu nad Moselou, byl zhotoven, podobně jako obuv z Nečtin, jen z usně (GALL 1980, inv. č. 6.12.22).

\section{Rozbor fragmentů textilu}

Z oděvu užitého $\mathrm{k}$ pohřbu se zachovalo celkem 33 fragmentů textilu. V souboru jsou zastoupeny čtyři typy textilií - hedvábné plátno, vlna v keprové vazbě nevalchovaná, vlna v keprové vazbě valchovaná a vlněné sukno v plátnové vazbě. $V$ důsledku rozkladných procesů změnily všechny jmenované textilie barvu.

\section{Hedvábí}

Jedná se o hedvábné plátno v dostavě $35 / 35$ nití na cm původně pravděpodobně světlé, snad krémové, barvy. Dochovalo se celkem šest fragmentů se známkami krejčovské úpravy. Vzhledem $\mathrm{k}$ nedostatku materiálu nelze odhadnout, jakého kusu oděvu byly tyto fragmenty součástí.

\section{Vlněný kepr}

Jedná se o tři fragmenty dvou různých látek. Fragment T07 byl utkán v dvouvazném kepru bez dalších úprav. Fragmenty T08 a T09 nesou stopy valchování na povrchu. U T09 vazba více prosvítá. Vzhledem k nedostatku materiálu nelze odhadnout, jakého kusu oděvu byly tyto fragmenty součástí.

\section{Vlněné sukno}

Největší konvolut fragmentů byl zhotoven v plátnové vazbě bez dalších povrchových úprav. Barva materiálu je dnes světle hnědá, pravděpodobně se původně jednalo o materiál př́rodní světlé barvy. Konvolut čítá celkem 24 kusů textilních fragmentů s pozůstatky krejčovské práce švů se zbytky šicích nití a několika knoflíkových dírek. Knoflíkové dírky se nacházejí na fragmentech T24, T25 a T31. Dírky jsou obšívané jednosmyčkovým stehem, jsou poměrně dlouhé vzhledem k zachovaným knoflíkům na fragmentu T31 (obr. 16). Podle sklonu vazby na fragmentu T31 lze předpokládat, že se jednalo o dolní zakončení předních dílů svrchního oděvu. Dírky jsou pečlivě krejčovsky vypracovány. Díky detailnímu vypracování můžeme předpokládat, že 


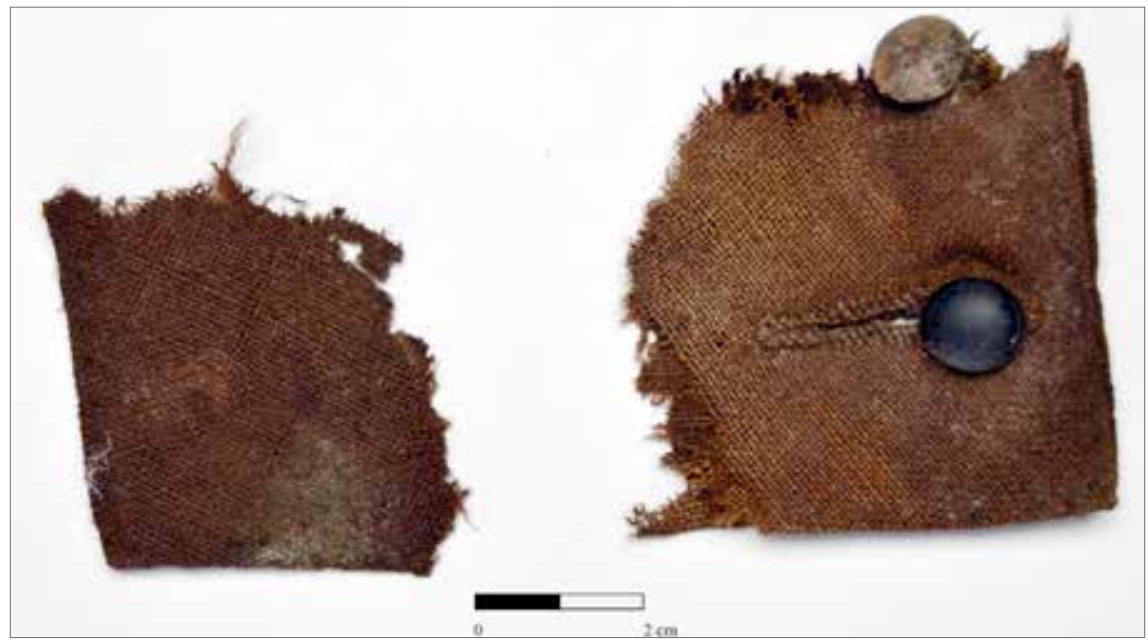

Obr. 16. Fragment T31 s knoflíky a dírkami a fragment T32. Foto Monika Zemánková.

Abb. 16. Fragment T31 mit Knöpfen und Löchern und Fragment T32. Foto Monika Zemánková.

se pravděpodobně nejednalo o oděv určený výhradně k pohřbu. Na přední straně byl oděv zřejmě celý propínací. Na fragmentu T31 se zachovaly také dva kusy černých kulovitých knoflíků na stopce vyrobených z pevného, blíže neurčeného materiálu.

\section{Analogie}

Co se týče řešení svrchního oděvu, lze časově i místně nejblíže porovnávat nález s pohřební výbavou z kostela Nejsvětější Trojice ve Valči (Prekop a kol. 2011). V pohřební výbavě ženy byl nalezen dlouhý soukenný kabát na způsob kleriky, který byl na přední straně opatřen dlouhým zapínáním. Řešení zapínání nápadně připomíná zachované zbytky knoflíkových dírek z fragmentu T31 (obr. 16). Analogie tohoto nálezu však byla v době vyhodnocování velmi komplikovaná, protože k dochovanému oděvu z Valče nebyla nalezena jasná ikonografická paralela mezi dámskými oděvy.

\section{Shrnutí a závěr}

Rozbor nálezového souboru proběhl se snahou pokusit se o identifikaci pohřbeného jedince a určit dobu jeho uložení do hrobky v kostele sv. Jakuba Většího v Nečtinech.

Předpokládanou dobu uložení jedince do hrobky vymezuje přestavba kostela $\mathrm{v}$ letech 1750-1752 a rezoluce Josefa II. zakazující pohřbívání v kostelech a hrobkách, vydaná 21. 3. 1782, popř́ípadě dvorní rozhodnutí ze dne 1. 12. 1783 rušící zcela rodinné hrobky v kostelech.

Klenuté hrobové komory jsou v oblasti stř̌ední Evropy známé od 15. století, od roku 1600 se objevují první cihlové hrobky (Králíková 2007, 87). Cihlové klenuté hrobky ze 17. a 18. století byly zkoumány v klášteře sv. Jiří na Pražském hradě (Borkovský 1969, 111; 1975, 45, 47; Tomková 2005, 193), v kostele Zvěstování Panny Marie v Chebu (Šebesta 1989, 123), v kostele Nejsvětější Trojice v Chrasti nad Hornádom (Slivka 1982, 389) a ve švýcarském Wangen an der Aare (Eggenberger et al. 1983, 231, Abb. 12).

Nalezená pohřební výbava sestávala z kompletního páru pantoflů, který tvarově odpovídá druhé polovině 18. století, a pohřebního oděvu. Textilní části souboru nelze jednoznačně přiřadit k chronologicky citlivějším typům oděvů, nebot' pro přesnější určení se zachovalo málo materiálu. 
Pro datování pohřbu byly důležité nalezené devocionálie, byt' je nutné počítat s tím, že lze odhadnout pouze datum post quem. V Nečtinech byl vyzdvižen tzv. kř́íž do ruky, odpustkový kříž, který věřící ve svých posledních chvílích svíral v ruce a se kterým byl následně uložen do hrobu. Kříž zaopatřený církevními odpustky měl umírajícímu pomoci ke vstupu na nebesa. Vedle kř́iže do ruky byla $z$ hrobky vyzdvižena i část rozpadlého růžence, přesněji řečeno jeho kovové součásti spolu s neúplným torzem dřevěného, původně latinského, křížku náležícího pravděpodobně k produkci řezbářů z oblasti Oberammergau. Dále k růženci náležel mosazný kř́ižek s vyobrazením Krista na jedné a postavy Jana Nepomuckého na druhé straně kříže, mosazná obecně ochranná svátostka propagující kult Panny Marie a Ježíše Krista a medailka s postavou sv. Benedikta a motivem Benediktova znamení. $Z$ hlediska celkového provedení lze popisované devocionálie zařadit jistě do druhé poloviny 18. století, pravděpodobněji do poslední třetiny 18. století s tím, že v oblasti Oberammergau se kříže stejného provedení vyráběly ještě $\mathrm{v}$ průběhu 19. století. Zejména rozbor devocionálií tedy přispěl k zpřesnění datace pohřbu mezi přelom druhé a třetí třetiny 18 . století a rok 1782 .

Špatný stav zachovalosti kosterních ostatků poměrně komplikoval určení pohlaví jedince metodami biologické antropologie. Dvě primární metody jej tedy určily jako indiferentního, třetí z $98 \%$ posteriorní pravděpodobností jako muže, byt' s řadou výhrad. Pro určení jedince byly využity pouze metrické a makroskopické metody. Při finančně výraznějších možnostech, než jaké byly k dispozici v rámci tohoto zjištovacího výzkumu, by bylo možné využít chemické či mikroskopické analýzy. Tyto metody mají velký informační potenciál pro sledování různých faktorů života a smrti jedince. $V$ tomto případě by k přsesnějšímu odhadu pohlaví přispěla analýza endogenní DNA, pro sledování zdravotního stavu jedince analýza exogenní DNA.

Každopádně antropologické odhady i interpretace fragmentů usně jako pánských pantoflů naznačují, že v hrobce byl uložen muž. Věk byl podle obrusu zubů odhadnut okolo 30 let a podle obliterace švů mezi 20-39 roky, šlo tedy o dospělého jedince. Na základě délky pravé loketní kosti byla výška postavy odhadnuta do rozmezí 168,5-178,5 cm.

V rámci pátrání po identitě vyzdviženého jedince byly zpracovávány záznamy o pohřbech uskutečněných při farním kostele sv. Jakuba Většího v Nečtinech v letech 1735 až 1800, zapsaných v matričních knihách zemřelých. S určitostí bylo potvrzeno šest pohřbů provedených v interiéru kostela. Jednalo se o uložení ostatků čtyř dospělých žen a dvou mužů zemřelých v letech 1756-1771, náležejících k místní společenské elitě (manželky zámeckého úředníka, členové hraběcí rodiny Kokořovců, místní duchovní správce). U patnácti dalších pohřbů běžných místních obyvatel z let 1760-1761, u nichž se v matričním zápisu objevuje jako místo uložení rovněž „in Ecclesia S. Jacobi Maj.“, tedy do kostela sv. Jakuba Většího, lze o takové lokalizaci pochybovat. $\mathrm{V}$ jejich př́ipadě se může jednat pouze o neobratnou formulaci zapisovatele.

Většina $\mathrm{z}$ výše uvedených pohřbů byla uložena v prostoru presbytáře. Jediným nelokalizovaným pohřbeným v interiéru kostela zůstává místní dlouholetý farní správce Martin Kunerl, který zde byl pochován v listopadu roku 1771, tedy v intervalu vymezeném rozborem devocionálií. Nabízí se možnost srovnání s nedalekým Manětínem, kde ve farním kostele Jana Křtitele byli $\mathrm{v}$ průběhu 18. století pohřbeni hned dva faráři, kteří si v prostoru kostela předem zvolili místo svého posledního odpočinku. Aleš Plešner si přál být pohřben pod kazatelnou (Wonka 1937, 21, 22), František Händl si nechal vybudovat v předsíňce před hlavním vchodem kryptu (Wonka 1937, 38). Věk zemřelého farního správce z Nečtin však neodpovídá závěrům antropologického odhadu, a to i přes veškeré výhrady způsobené nízkou zachovalostí kosterního materiálu. Svrchní oděv, v kterém byl zemřelý pohřben, připomínal řešením zapínání kabát na způsob kleriky. Dobře zachovalý kněžský šat, sestávající i z kleriky, byl odkryt v rakvi kněze v Louňovicích pohřbeného v roce 1687 (Radoměrský 1966, 31). V hrobce v Nečtinech však chybí doklady dalších atributů, které bývají součástí hrobů duchovních osob, jako je kalich (Borkovský 1975, 55, 94; Kováčik-Dudková-Lafková 2016, 190, obr. 21; Šolle-Váňa 1983, 27; Šolle 1990, 190) nebo kovové identifikační tabulky (Unger 2000, 351). Hrob kněze měl být podle Rituale Romanum, schváleného katolickou církví roku 1614, orientován opačně, tedy východozápadně s hlavou k východu, toto pravidlo však již nebylo v 18. století důsledně dodržováno (Králíková 2007, 105). 
Přes veškerou snahu a interdisciplinární spolupráci archeologů, antropologů, historiků a archivářủ se nepodařilo nalezeného jedince jednoznačně identifikovat. Nadměrná vlhkost v interiéru kostela primárně negativně determinovala zachování kosterního materiálu i pohřebního oděvu. Sekundárně vytvořila vhodné prostředí pro růst hub a plísní, což byly další faktory, které přispěly k devalvaci nálezového souboru. Dostatečně průkazné nebyly ani zápisy v matrikách, které se mnohdy omezily pouze na uvedení názvu obce, kde byl zemřelý pohřben. Přesto se podařilo získat zajímavé doklady $\mathrm{k}$ dějinám odívání a pohřebního ritu na území Čech v období raného novověku.

\section{Prameny a literatura}

BELLO, S. M. et al., 2006: Bello, S. M.-Thomann, A.-Signoli, M.-Dutour, O.-Andrews, P., Age and sex bias in the reconstruction of the past population structures, American Journal of Physical Anthropology 129, 24-38. https://doi.org/10.1002/ajpa.20243

BOHÁČ, Z., 1973: Patrocinia jako jeden z pramenů k dějinám osídlení, ČČH 21, 369-388.

BORKOVSKÝ, I., 1969: Pražský hrad v době přemyslovských knížat. Praha.

- 1975: Svatojiřská bazilika a klášter na Pražském hradě. Monumenta archaeologica 18. Praha.

BRAVERMANOVÁ, M.-ČIERNA, A., 1997: Pohřební textilie z hrobu Rudolfa II. v královské hrobce v katedrále sv. Víta na Pražském hradě - Leichentextilien aus dem Grab des Rudolf II. aus der Königsgruft im St. Veitsdom in der Prager Burg, AH 22, 363-385.

BRAVERMANOVÁ, M.-KOBRLOVÁ, J.-SAMOHÝLOVÁ, A., 1995: Textilie z hrobu Maxmiliána II. Habsburského z Colinova mauzolea v katedrále sv. Víta na Pražském hradě - Textilien aus dem Grab des Maxmilian II. von Habsburg aus dem Colin-Mausoleum im St. Veitsdom in der Prager Burg, AH 20, 497-521.

BRAVERMANOVÁ, M.-LUTOVSKÝ, M., 2001: Hroby, hrobky a pohřebiště českých knížat a králů. Praha.

BUIKSTRA, J. E.-UBELAKER, D. H., 1994: Standards for data collection from human skeletal remains. Fayetteville, Arkansas.

CAPASSO, L.-KENNEDY, A. R.-WILCZAK, C. A., 1999: Atlas of occupational markers on human remains. Teramo, Italy.

CDB I: Codex diplomaticus et epistolaris regni Bohemiae I., 805-1197 (Friedrich, G., ed.). Pragae 1904-1907.

DIDEROT, D.-D’ALEMBERT, J., 1763: Encyclopedie, ou Dictionnaire raisonné des science, des artes et des métiers. Díl II. Paris.

DRC: Decem registra censuum Bohemica compilata aetate bellum husiticum praecedente (Emler, J., ed.). Praha 1881.

DUDKOVÁ, V. a kol., 2018: Dudková, V.-Orna, J.-Lungová, V.-Šneberger, J.-Omelka, M., Výzkum u kostela sv. Petra a Pavla v Liticích - Archaeological research in the grounds of the Church of Sts. Peter and Paul, Litice - Die Grabung an der St. Peter-und-Paul-Kirche in Litice, AH 43, 35-49.

FLOHR, S.-SCHULTZ, M., 2009: Osseous Changes due to Mastoiditis in Human Skeletal Remains, International Journal of Osteoarchaeology 19, 99-106. https://doi.org/10.1002/oa.961

FROLÍK, J., 2017: Pohřbívání ve vrcholném středověku a v novověku na Chrudimsku, Pardubicku a Kolínsku - Bestattungen im Hochmittelalter und in der Neuzeit in den Regionen Chrudim, Pardubice und Kolín, AH 42, 187-205.

GALETA, P. a kol., 2015: Galeta, P.-Šneberger, J.-Frídl, L.-Pankowská, A.-Jurman, K.-Kubátová, I., Katalog kosterního souboru ze hřbitova u kostela sv. Máŕí Magdaleny v Plzni. Plzeň.

GALL, G., 1980: Deutsche Schuhmuseum. Würzburg.

GORDON, C. C.-BUIKSTRA, J. E., 1981: Soil pH, Bone Preservation, and Sampling Bias at Mortuary Sites, American Antiquity 46, No. 3, 566-571. https://doi.org/10.2307/280601

GOUBITZ, O., 2007: Stepping through Time - Archaeological Footwear from Prehistoric Time until 1800. Zwolle.

HEDGES, R. E. M., 2002: Bone Diagenesis: An Overview of Processes, Archaeometry 44, 319-328. https:// doi.org/10.1111/1475-4754.00064

KELLER, P. (ed.), 2010: Edelsteine \& Himmesschüre. Rosenkränze \& Gebetsketten. Salzburg.

- 2010a: Glaube \& Aberglaube. Amulette, Medaillen \& Andachtsbildchen. Salzburg.

KNOFLÍČEK, Z., 1995: Kostel sv. Jakuba Většího v Nečtinech. Stavebně-historický průzkum, rkp. ulož. $\mathrm{v}$ archivu odd. starších dějin Západočeského muzea v Plzni. 
KNOLL, V., 2003: Panská sídla v Nečtinách a okolí. Plzeň.

KOČKA, V., 1932: Dějiny politického okresu Kralovického. Díl II. Soudní okres Manětínský. Kralovice.

KOVÁČIK, P.-DUDKOVÁ, V.-LAFKOVÁ, H., 2016: Poznatky ke stavebnímu vývoji a k pohřbívání v kostele sv. Kříže v Javorníku-vsi na základě archeologického výzkumu, PV 57, č. 2, 177-196.

KRÁLÍKOVÁ, M., 2007: Pohřební ritus 16.-18. století na území střední Evropy: (antropologicko-archeologická studie). Panoráma antropologie biologické - sociální - kulturní. Modulové učební texty pro studenty antropologie a „příbuzných oborü“ 35 . Brno.

- 2017: Pohřbívání na Moravě v 16.-18. století - Bestattungen in Mähren im 16.-18. Jahrhundert, AH 42 , 135-151.

LAVAL, F., 2016: Co je kostel? K počátkům šlechtických sídel českého středověku - On the beginnings of aristocratic seats in medieval Czech lands, AR LXVII, 47-90.

LOVEJOY, C. O., 1985: Dental wear in the Libben population: Its pattern and role in the determination of adult skeletal age at death, American Journal of Physical Anthropology 68, 47-56. https://doi.org/10.1002/ ajpa.1330680105

MASSET, C., 1989: Age Estimation on the Basis of Cranial sutures. In: Age Markers in the Human Skeleton (Iscan, M. Y., ed.), 71-103. Springfield.

NEČTINY 20, 22 a 29: Státní oblastní archiv v Plzni, Sbírka matrik západních Čech, sign. Nečtiny 20 (1784-1846), Nečtiny 22 (1784-1883) a Nečtiny 29 (1735-1784).

OMELKA, M., 2006: Nález neobvykle členěného medailonu s vyobrazením kříže svatého Benedikta a Zachariášova požehnání ze Šporkovy ulice čp. 332/III v Praze, Archeologica Pragensia 18, 144-152.

OMELKA, M.-ŘEBOUNOVÁ, O., 2008: Soubor korálků ze zaniklého hřbitova při kostelu sv. Jana v Oboře (Praha-Malá Strana), ASČ 12, 605-679.

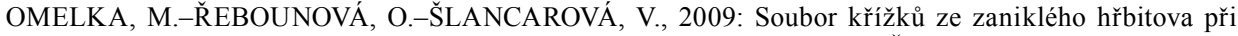
kostelu sv. Jana v Oboře (Praha-Malá Strana). I. Obecné formy kříže, ASČ 13, 1001-1083.

- 2010: Soubor křížků ze zaniklého hřbitova při kostelu sv. Jana v Oboře (Praha-Malá Strana). II. Speciální kříže, ASČ 14, 423-476.

ORNA, J. a kol., 2018: Orna, J.-Šneberger, J.-Omelka, M.-Pilná, V., Nečtiny, kostel sv. Jakuba. Zpráva o provedení zjišt'ovacího archeologického výzkumu, rkp. ulož. v archivu odd. starších dějin Západočeského muzea v Plzni.

PREKOP, F. a kol., 2011: Prekop, F.-Králíková, M.-Otavská, V.-Postránecká, K.-Průchová, E., Nález neznámého jedince pohřbeného v kostele Nejsvětější Trojice ve Valči, Sborník Muzea Karlovarského kraje 19, 373-390.

RADOMĚRSKÝ, P., 1966: Blaník a Louňovice pod Blaníkem. Praha.

RBM: Regesta diplomatica nec non epistolaria Bohemiae et Moraviae VI/1, 1355-1356 (Mendl, B., ed.). Praha 1928.

SJØVOLD, T., 1990: Estimation of stature from long bones utilizing the line of organic correlation, Human Evolution 5, 431-447. https://doi.org/10.1007/BF02435593

SLIVKA, M., 1982: Výsledky výskumu kostola v Chrasti nad Hornádom, okr. Sp. Nová Ves - Die Erforschung der Kirche in Chrast nad Hornádom. Bez. Spišská Nová Ves und ihre Ergebnisse, AH 7, 385-411.

ŠEBESTA, P., 1989: Nové příspěvky ke stavebnímu vývoji Chebu - Neue Beiträge zur Bauentwicklung Chebs im 13. Jahrh., AH 14, 123-130.

ŠOLLE, M., 1990: Rotunda sv. Petra a Pavla na Budči, PA LXXXI, 140-207.

ŠOLLE, M.-VÁŇA, Z., 1983: Budeč - památník českého dávnověku. Kladno.

ŠTÝBROVÁ, M., 2009: Dějiny odívání - Boty, botky, botičky. Praha.

TOMKOVÁ, K., 2005: Pohřební ritus na Pražském hradě a jeho předpolích ve středověku a novověku charakteristika a vývoj. In: Castrum Pragense. Pohřbívání na Pražském hradě a jeho předpolích 1.1 (Tomková, K., ed.), 159-196. Praha.

UNGER, J., 2000: Pohřební ritus městského obyvatelstva 13. až 18. století v archeologických pramenech Moravy a Slezska - Der Grabritus der städtischen Bevölkerung im 13. bis 18. Jh. in archäologischen Quellen Mährens und Schlesiens, AH 25, 335-356.

VAŇKOVÁ, L.-PILNÁ, V., 2013: Metodika datování a interpretace portrétů 16.-18. století pomocí historické módy. Praha.

WALRATH, D. E.-TURNER, P.-BRUZEK, J., 2004: Reliability test of the Visual Assessment of Cranial Traits for sex Determination, American Journal of Physical Anthropology 125, 132-137. https:/doi. org/10.1002/ajpa.10373

WONKA, F., 1937: Kniha o faře manětínské I., rkp. ulož. v SOkA Plzeň-sever, fond Wonka František, EL NAD č. 1251.

ZEZULA, M., 2011: Kostel sv. Martina ve světle archeologického výzkumu. In: Kozák, P.-Prix, D.-Zezula, M. a kol., Kostel sv. Martina v Bohušově, 172-178. Ostrava. 


\section{Zusammenfassung}

\section{Untersuchung einer neuzeitlichen Gruft in der Kirche St. Jakobus der Ältere in Nečtiny}

Die Analyse des beschriebenen Fundensembles erfolgte mit dem Bestreben, die Identifizierung eines bestatteten Individuums zu versuchen und die Zeit zu bestimmen, wann seine Beisetzung in der Gruft der Kirche St. Jakobus der Ältere in Nečtiny erfolgte.

Die angenommene Zeit der Grablegung des Individuums wird durch den in den Jahren 1750 1752 erfolgten Umbau der Kirche und durch die von Josef II. am 21. 3. 1782 erlassene Resolution des Verbots der Durchführung von Bestattungen in Kirchen und Gruften, ggf. durch die Hofentscheidung vom 1. 12. 1783 umgrenzt, durch welche Familiengruften in Kirchen völlig abgeschafft wurden. Diesem Intervall entspricht der Fund der Grabbeigabe eines kompletten Pantoffelpaares, das hinsichtlich seiner Form der zweiten Hälfte des 18. Jahrhunderts entspricht. Der Textilteil des Fundensembles lässt sich chronologisch sensibleren Begleitungstypen nicht eindeutig zuordnen, da für eine genauere Bestimmung zu wenig Material erhalten geblieben ist.

Für die Datierung der Bestattung waren die gefundenen Devotionalien wichtig, obgleich auch damit gerechnet werden muss, dass man lediglich ein Datum post quem abschätzen kann. In Nečtiny wurde ein sog. Handkreuz, ein Ablasskreuz, das der Gläubige in seinen letzten Momenten mit der Hand umschloss und anschließend damit ins Grab gelegt wurde. Das mit einem kirchlichen Ablass versehene Kreuz sollte dem Sterbenden beim Eintritt in den Himmel beistehen. Neben dem Handkreuz wurde aus der Gruft auch das Fragment eines zerfallenen Rosenkranzes gehoben, genauer gesagt dessen Metallbestandteil zusammen mit dem unvollständigen Torso eines ursprünglich lateinischen Holzkreuzchens, das wahrscheinlich zur Produktion der aus der Oberammergauer Region stammenden Schnitzer gehört. Ferner gehörte ein kleines Messingkreuz zum Rosenkranz, das auf der einen Seite Christus und auf der anderen Johannes von Nepomuk zeigt, ein den Marien- und Jesuskult propagierendes Schutzmedaillon aus Messing und ein Medaillon mit der Figur des H1. Benedikt und dem Motiv von Benedikts Zeichen. Im Hinblick auf ihre Gesamtausführung lassen sich die beschriebenen Devotionalien sicher der zweiten Hälfte des 18. Jahrhunderts zuordnen, wahrscheinlich dem letzten Drittel des 18. Jahrhunderts, wobei in der Gegend von Oberammergau noch im 19. Jahrhundert Kreuze gleicher Ausführung hergestellt wurden.

Besonders die Analyse der Devotionalien hat zu einer Präzisierung der Datierung der Beisetzung in die Zeit zwischen der Wende des zweiten und dritten Drittels des 18. Jahrhunderts und dem Jahr 1782 beigetragen.

Der schlechte Erhaltungszustand der Skelettüberreste hat eine Bestimmung des Geschlechts des Individuums mit den Methoden der biologischen Anthropologie ziemlich erschwert. Die zwei primären Methoden haben es demnach als indifferent bestimmt, die dritte mit einer a-posteriori Wahrscheinlichkeit von $98 \%$ als Mann, wenn auch mit einer Reihe Vorbehalte.

Für die Bestimmung des Individuums wurden lediglich metrische und makroskopische Methoden verwendet. Bei kostenträchtigeren Möglichkeiten, als im Rahmen dieser Feststellungsuntersuchung zur Verfügung standen, hätten chemische bzw. mikroskopische Analysen herangezogen werden können. Diese Methoden haben ein großes Informationspotenzial dafür, verschiedene Faktoren bzgl. Leben und Tod eines Individuums zu beobachten. In diesem Fall hätte eine Analyse der endogenen DNA zu einer genaueren Bestimmung des Geschlechtes beigetragen, für die Erfassung des Gesundheitszustandes des Individuums dann eine Analyse der exogenen DNA.

Jedenfalls deuten die anthropologischen Einschätzungen und die Interpretation der Lederfragmente als Herrenpantoffeln darauf hin, dass in der Gruft ein Mann beigesetzt wurde. Das Alter wurde dem Zahnabrieb entsprechend auf um die 30 Jahre geschätzt und der Obliteration der Nähte nach auf zwischen 20-39 Jahre, es handelte sich also um ein erwachsenes Individuum. Aufgrund der Länge des rechten Ellenbogenknochens wurde die Körpergröße auf die Spanne zwischen $168,5-178,5 \mathrm{~cm}$ geschätzt.

Im Rahmen der Nachforschungen über die Identität des gehobenen Individuums wurden die Aufzeichnungen über die an der Pfarrkirche St. Jakobus der Ältere in Nečtiny in den Jahren 
1735 bis 1800 durchgeführten Bestattungen ausgewertet, die sich in den Sterbematrikelbüchern befanden. Sicher bestätigt wurden sechs im Kircheninnern durchgeführte Beisetzungen. Dabei handelte es sich um die Beisetzung der Gebeine von vier erwachsenen Frauen und zweier Männer, die in den Jahren 1756-1771 verstarben und zur örtlichen gesellschaftlichen Elite gehörten (Ehefrau eines Schlossbeamten, Mitglieder der Grafenfamilie von Kokořov, ein örtlicher Verwaltungsgeistlicher). Bei fünfzehn weiteren Beisetzungen gewöhnlicher örtlicher Einwohner aus den Jahren 1760-1761, bei denen im Sterbematrikeleintrag als Beisetzungsort ebenfalls ,in Ecclesia S. Jacobi Maj.“ auftaucht, d.h. in der Kirche St. Jakobus der Ältere, kann eine solche Lokalisierung angezweifelt werden. In ihrem Fall kann es sich nur um eine ungelenke Formulierung des Matrikelschreibers handeln.

Die meisten der oben aufgeführten Bestattungen wurden im Chorraum beigesetzt. Der einzige im Kircheninnern nicht lokalisierte Bestattete bleibt der langjährige örtliche Pfarreiverwalter Martin Kunerl, der dort im November des Jahres 1771 beigesetzt wurde, d.h. in dem von der Analyse der Devotionalien abgegrenzten Intervall. Hier bietet sich eine Vergleichsmöglichkeit mit der nahegelegenen Stadt Manětín an, wo in der Pfarrkirche Johannes der Täufer im Laufe des 18. Jahrhunderts gleich zwei Pfarrer bestattet wurden, die sich den Ort ihrer letzten Ruhestätte im Kircheninnern im voraus aussuchten. Das Alter des verstorbenen Pfarreiverwalters aus Nečtiny entspricht jedoch nicht den Schlussfolgerungen der anthropologischen Bestimmung, und zwar auch trotz jeglicher durch den schlechten Erhaltungsgrad des Knochenmaterials bedingten Vorbehalte. Die Oberbekleidung, in welcher der Verstorbene beigesetzt wurde, erinnert in ihrer Ausführung einem Mantelverschluss nach Art eines Klerikers. Im Grab von Nečtiny fehlen jedoch die Belege weiterer Attribute, die man in die Gräber von Geistlichen als Beigabe hineinzulegen pflegte, wie etwa ein Kelch oder Identifikationstäfelchen aus Metall es sind.

Trotz aller Bemühungen und interdisziplinärer Zusammenarbeit zwischen Archäologen, Anthropologen, Historikern und Archivaren ist es nicht gelungen, das entdeckte Individuum eindeutig zu identifizieren. Die übermäßige Feuchtigkeit im Kircheninnern hat die Erhaltung des Knochenmaterials und der Bestattungskleidung primär negativ beeinflusst. Sekundär schuf sie geeignete Bedingungen für Pilzwuchs und Schimmelbefall, was weitere Faktoren waren, die dazu beitrugen, den Erhaltungszustand des Fundensembles zu verschlechtern. Auch die Matrikeleinträge waren nicht beweiskräftig genug und beschränkten sich häufig lediglich auf die Angabe des Namens der Gemeinde, in der die Verstorbenen beigesetzt wurden. Trotzdem konnten interessante Belege herangezogen werden, die über die in Böhmen in der frühen Neuzeit für Begräbnisse verwendete Kleidung und über den Begräbnisritus jener Zeit Auskunft geben.

Mgr. Jiří Orna, Západočeské muzeum v Plzni, Kopeckého sady 2, 30100 Plzeň, Česká republika, jorna@zcm.cz

Mgr. Jiří Šneberger, Západočeské muzeum v Plzni, Kopeckého sady 2, 30100 Plzeň; Př́rodovědecká fakulta Univerzity Karlovy, Albertov 6, 12843 Praha, Česká republika,jsneberger@zcm.cz

PhDr. Martin Omelka, Archiv hlavního města Prahy, Archivní 6, 14900 Praha 4, Česká republika, Martin.Omelka@praha.eu

Mgr. Otakara Řebounová, Archiv hlavního města Prahy, Archivní 6, 14900 Praha 4, Česká republika, Otakara.Rebounova@praha.eu

Veronika Pilná, Ph.D., Národní památkový ústav, územní odborné pracoviště v Plzni, Prešovská 7, 30637 Plzeň, Česká republika, pilna.veronika@npu.cz 
